\title{
Curriculum System Construction on Applied Japanese Talents Training
}

\author{
Yanjun Liu \\ Liaoning Institute of Science and Engineering, Jinzhou, 121013, China \\ piaomiao0411@126.com
}

Keywords: applied Japanese talents; training mode; curriculum system; implementation strategies

\begin{abstract}
The curriculum system is the sum of the teaching content and the process, which is a complete unity composed of various courses, and determines what kind of knowledge structure students will learn through. This paper aims at the actual situation of the demand of Japanese talents in economic and social development, and provides a solution for improving the quality of applied Japanese talents. Based on the principle of curriculum system construction, the research content is based on the design of "General education curriculum, Discipline platform curriculum, Professional basic curriculum, Professional orientation curriculum and Practice teaching link", which is based on the specific ability of professional competence and individual ability architecture, and put forward the application of Japanese language training system implementation strategy. The successful application of the research results in this paper plays an important role in improving the quality of applied Japanese talents.
\end{abstract}

\section{Introduction}

Curriculum system refers to the same professional courses in different categories according to the order, is the sum of teaching content and process, and the order of the curriculum category determines the students through the study will get what kind of knowledge structure [1]. Curriculum system is the guiding ideology of educational activities, is the specific training objectives and rely on the provisions of the implementation on the planning program. The curriculum system is mainly composed of a specific curriculum view, curriculum objectives, curriculum content, curriculum structure and curriculum activities, which plays a dominant role in curriculum view. The reform of curriculum system of higher education is based on the needs of social development, adapting to the development of students as the focus, the reorganization and integration of knowledge system, and combining the formation of knowledge logic and problem innovation to the innovative curriculum system.

In the era of planned economy, China's higher education is a single "professional" training mode. However, with the rapid development of economic society, this training model gradually exposed the drawbacks of students with narrow knowledge, poor adaptability and ability to create. Although the tone of foreign language students is good, but the lack of comprehensive knowledge reflect the contradictions between institutions of higher education and market demand. Application for talents, that is, colleges and universities according to the actual needs of the society, for the actual and production line, to master a certain basic theoretical knowledge and the corresponding scientific research achievements into the talents, with the "special talents", "theoretical talents "or" academic talents "corresponding to the different types of talents. In order to adapt to the needs of the market, the current higher education Japanese major mainly cultivates two types of talents, the first is with the solid Japanese language skills, and with strong academic language, literature and cultural knowledge talents; the second is with solid Japanese language skills , and with strong Japanese comprehensive and communicative ability, with a certain degree of computer knowledge, scientific and technological knowledge and economic and trade knowledge of the application of Japanese talents. In order to adapt to the market demand for Japanese talents, this paper studies the construction of the Japanese language training system, and provides a solution to improve the quality of Japanese talents. 


\section{Principle of Curriculum System Construction}

The purpose of training Japanese talents is to adapt to the needs of regional economic and social development, both ability and political integrity, with a solid foundation of Japanese language, extensive cultural knowledge, high personality culture, strong professional practice skill and innovative spirit, and to be familiar with the use of Japanese in foreign affairs, trade, education, technology enterprises and other talents engaged in translation, business, teaching and research work. For the training objectives, curriculum system construction should follow the following principles [2,3]:

(1) Unify the principle of comprehensiveness and systematization. Comprehensiveness and systematization are the most basic requirements for building a curriculum system. Comprehensiveness refers to the coverage of the course is large, all languages required to learn every knowledge and every knowledge points are included as much as possible; systematization is compatible with different courses and different knowledge points between the links to become a relatively complete system.

(2) Unify the principle of practicality and expansibility. Practicality refers to the curriculum choice should be adapted to the practical needs from the students and employers, in line with the objectives of higher education professional training, the content and requirements are clear, with specific, measurable, verifiable and operational features; Expansibility is in the need of curriculum choice to be forward-looking, easy to train students thinking, in line with the development trend of education.

(3) Unify the principle of disciplinization and adaptation. Disciplinization refers to the selection of curriculum content according to the structure of the subject, which is conducive to the inheritance and development of human culture, which is conducive to keeping the systematic and structural knowledge of the subject knowledge. Adaptation requires the choice of real life knowledge into the course, subject knowledge in real life, the use of subject knowledge to analyze the phenomenon of life, to solve practical problems.

(4) Unify the principle of improvement and universality. Improvement can enhance the comprehensive knowledge ability of students, the course content has a certain depth, and also has the characteristics of specialization, especially in the compulsory course to increase knowledge; universal knowledge requires students to understand a wide range of knowledge, expanding the knowledge of students, without need in deep study, especially in the elective course.

\section{Japanese Applied Talents Training Curriculum System}

Applied talents training curriculum system should be closely around the actual needs of the market, curriculum content and position close integration, attention to professional forward dynamic and related skills changes. To clear the professional ability and personal ability training-based, the implementation of the system curriculum, reasonable arrangements for progressive curriculum content, to achieve "live module, multi-directional" choice, to reduce classroom teaching time, and to strengthen self-learning, modular teaching flexible and diverse. The application of Japanese language training curriculum system consists of a variety of courses, each class according to the assessment method for classification. According to the assessment method can be divided into compulsory and elective courses. Among them, compulsory courses, refers to the professional training objectives and basic training specifications, requiring students to study the course and practical education and teaching links; elective courses, refers to professional students can choose to attend the course, some elective courses are for the introduction of advanced science and technology and the latest scientific results, some elective courses are to expand the students knowledge, and some elective courses are to meet the interests of students and develop their ability to a certain aspect. The composition of the Japanese language training system is shown in Fig. 1.

(1) General education curriculum. In addition to professional education outside the basic education curriculum, is the key to achieve the concept of universal education and objectives. Through the knowledge of the basic, holistic, comprehensive and broad, to broaden their horizons, 
to cultivate independent thinking judgment, social responsibility and healthy personality. The applied Japanese language talents in general education curriculum is divided into philosophy and social science accomplishment, humanistic accomplishment, natural science and technology accomplishment, aesthetic accomplishment, practical ability accomplishment and other five modules. Encourage students to make their own interdisciplinary and cross-disciplinary elective courses, the full development of individuality; encourage students to proceed from their own practice, so as to enhance students learning initiative, to improve the overall quality.

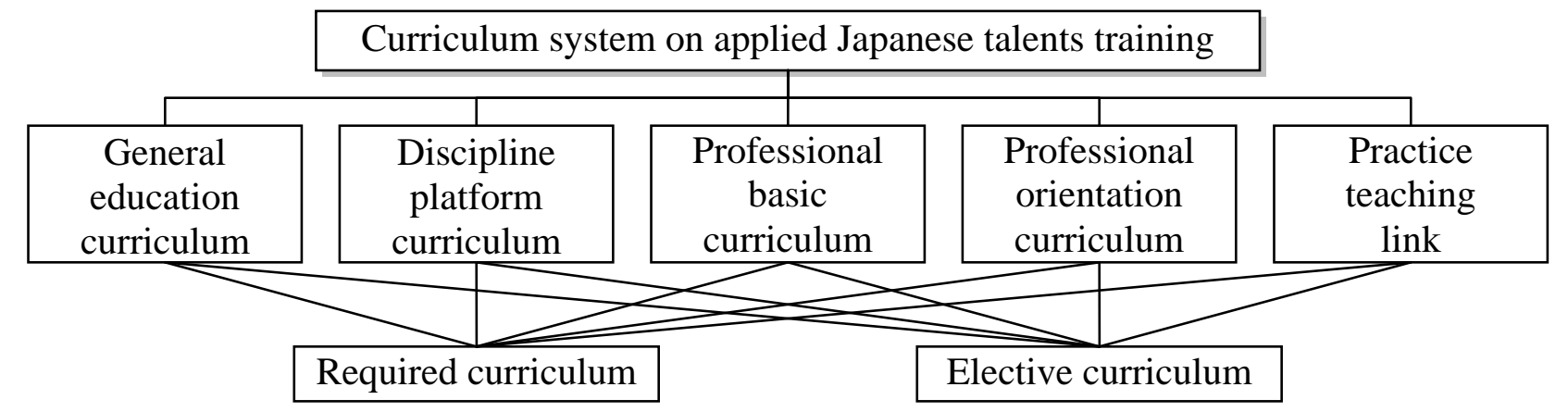

Fig. 1. Curriculum system on applied Japanese talents training

(2) Discipline platform curriculum. Mainly for the subject of basic courses, in accordance with the major categories of talents training and organization of teaching work, integration of educational content, optimize the curriculum structure, reinforce and broaden the student base, and increase the development potential of students. On the one hand, to integrate the teaching of different professional resources, unified teaching syllabus, unified assessment of links, on the other hand, to reform the teaching content, teaching methods, the formation of the unified module and network of quality courses. The Japanese applied language talents training program is mainly "integrated Japanese", which divided into four semesters; also includes "Japanese voice, Japanese spoken language, Japanese audio-visual and Japanese writing" and so on.

(3) Professional basic curriculum. This is the basic knowledge and skills directly linked to the basic course, and for students to study the prerequisite courses. Relatively generous professional basis, is conducive to students for professional learning and after graduation to adapt to social development and science and technology needs. The basic courses of the applied Japanese language talents include "Advanced Japanese" and "Japanese Intensive Reading". "Advanced Japanese" is divided into four semesters, "Japanese Intensive Reading" is divided into three semesters. Others include "Japanese Grammar, Japanese Extensive Reading, Introduction of Japanese Studies, Intertranslation, Second Foreign Language, Japanese Vocabulary, Japanese Language and Literature" and so on.

(4) Professional orientation curriculum. For the employment direction after graduation, each major has its own different research direction. However, due to the time and other factors, we can only study a direction, and the corresponding direction of the course, called professional direction class. Now the applied Japanese talents, the social is in urgent need of the following four directions, as shown in Fig. 2. Among them, Business Japanese, is able to use Japanese as a tool to master business knowledge, is familiar with secretarial work, and it can use a variety of modern office equipment, which is a moral, intellectual and physical development applied talents; Tourism Japanese, training tourism expertise and organizational activities, has competent expertise for tour guide, translator, team leader, travel agency management and so on. Japanese translation, with a solid Japanese language foundation and listening, speaking, reading, writing, interpreting, translation and other abilities, understand the Sino-Japanese society and culture, with a good Chinese communication skills; Language literature, master the discipline of the basic theory and system of professional knowledge, and in Japanese language literature and related field engaged in scientific research, management and teaching of high-quality foreign language talents.

(5) Practice teaching link. Practical teaching is an effective way to consolidate theoretical knowledge and deepen the understanding of theory. It is an important link to cultivate high-quality 
applied talents with innovative consciousness. It is an important platform for theory to practice and cultivate students to master scientific methods and improve the hands-on ability. It is conductive to the improvement of students' accomplishment and the formation of correct values. The practical teaching system of Japanese applied talents includes three levels: basic practice, language application practice and professional comprehensive skill practice. The basic practice includes professional and public service, entrance education military training, graduated education; language application practice includes oral communication ability, language conversion ability, writing ability, discourse analysis ability and specialized business ability; professional comprehensive skill practice includes professional skills, curriculum papers, graduation practice, graduation thesis, social practice.

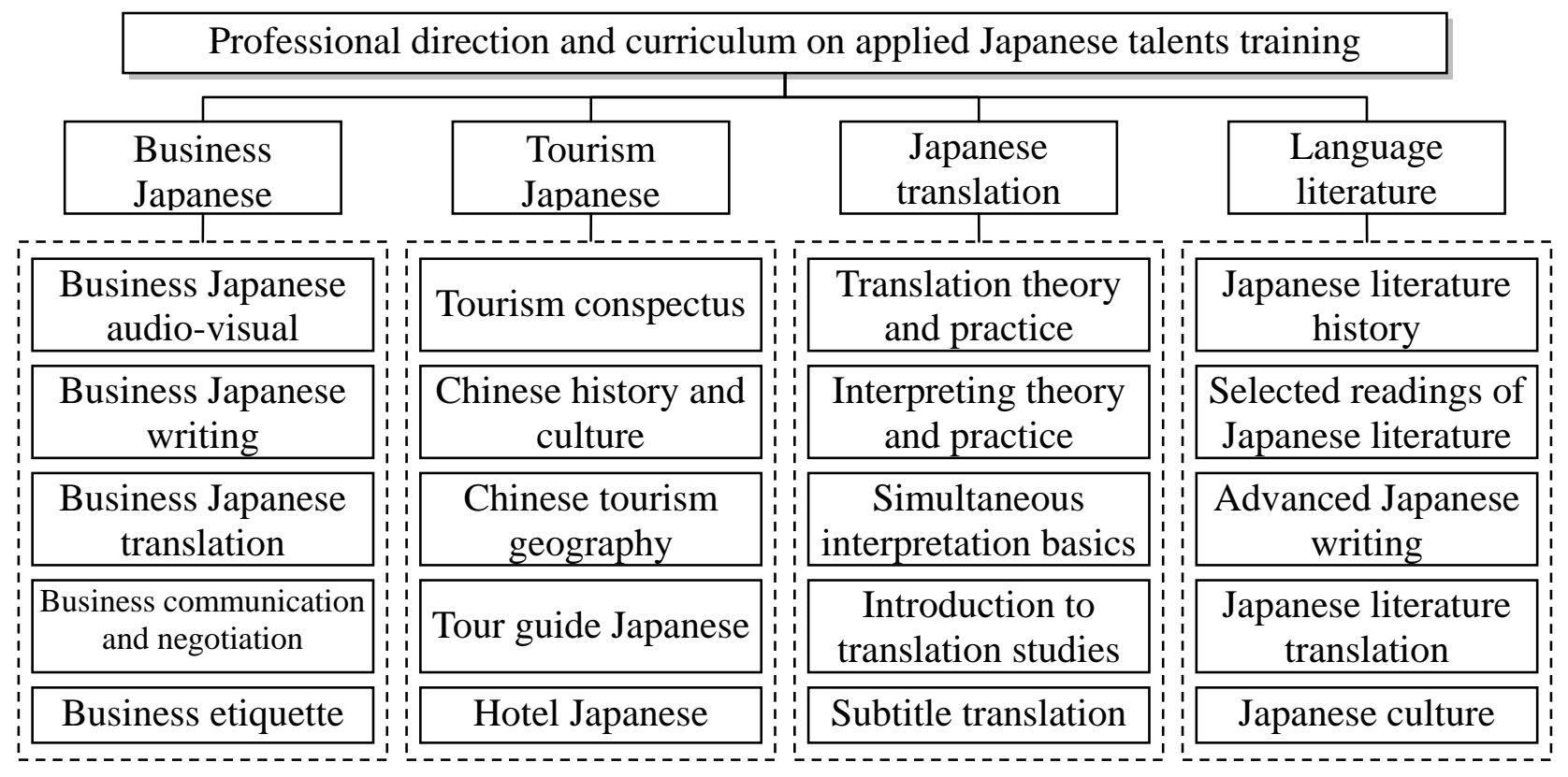

Fig. 2. Professional direction and curriculum on applied Japanese talents training

\section{Implementation Strategy of Japanese Applied Talents Training Curriculum System}

In order to improve the effectiveness of Japanese applied training curriculum system, according to the previous research results [4-7], we combined with the author's own years of practical teaching experience and summed up the implementation process to follow the following strategy:

(1) According to social needs to make training objectives. The goal of education is the materialization of educational institutions, which is an important basis for the construction of talents training system at all levels. It plays an important role in talents training and has a guiding stability, regulation and encouragement to the development of educational activities. Japanese applied talents are more and more welcomed by the society, which is the socialist market economy on the Japanese professional education put forward the new requirement. The specific training objectives are: solid Japanese language basic skills, broad knowledge, certain degree of language expertise and strong Japanese comprehensive applied ability; master a professional direction of the basic knowledge and basic skills; have access to knowledge, the use of information , independent thinking and the ability to innovate; have good learning habits and strong self-learning ability.

(2) Strengthen the introduction of Japanese culture. Language is the product of culture, but also the carrier of culture, the two are closely linked and inseparable. Therefore, language teaching and cultural teaching are also interactive and mutual promotion. We should pay attention to the introduction of culture in Japanese language teaching, mobilize the enthusiasm of students to learn Japanese, and improve the cross-cultural ability of both teachers and students. From the cultural point of view to teach language, rather than from the perspective of language. Cultural introduction includes two categories: one is the introduction of knowledge and culture, so that students understand the Japanese way of thinking and values to enhance the cultural accomplishment and 
cultural awareness; the other is the introduction of communicative culture, and specifically divided into non-verbal communication and communicative environment culture. Non-verbal communication refers to all the means of communication except the language, through the body language and exchange of language to observe others feelings. Communicative environment refers to the objective factors that constitute the language communication, communication must pay attention to and according to the communication environment.

(3) Strengthen the cultivation of students' communicative competence. The ultimate goal of language learning is to cultivate communicative competence. Communicative competence includes not only the understanding and mastery of language form, but also the understanding and mastery of the knowledge system of communication in any form and place in appropriate manner. And ask the teacher in the teaching process, more organizations to practice dialogue, set different situation, so that let the students to be self-expression. You can also use the textbook content to train students' communicative competence, so that students play the role of textbooks to practice dialogue, to further understand the Japanese language and culture. In real life, students can contact with Japanese friends, not only to learn the true cultural custom in Japan, but also enhance the ability to communicate.

(4) "Listening, speaking, reading, writing" 4 skills overall enhance. The comprehensive principle of language teaching not only emphasizes the synthesis of teaching methods, but also emphasizes the integration of language skills. "Listening, speaking, reading and writing" 4 skills are relatively independent, but also interrelated, to all-round development. Even in one-way skill class, teacher should also reflect the comprehensive principles of language skills. Listening and reading process is actually learners from outside to inside access to language knowledge of the input process, that is written and learners will learn the knowledge from the inside out of the output process. Language teaching must focus on input, absorption and output three links, so that students learn new knowledge into the long-term memory system, into the existing knowledge structure, the formation of their own language generation system. "Listening, speaking, reading, writing," comprehensive upgrade, not only reflects the language teaching should be based on the four kinds of skills into one of the overall language law, but also make the form of classroom teaching varied, to avoid single engaged in a language activities bored and uninterested, so as to keep students interested in learning.

\section{References}

[1] Think tank Wikipedia, "Curriculum system," http://wiki.mbalib.com/wiki/\%BB, 2017-1-10.

[2] J. H. Liu, "Several principles to be grasped in the course system construction of regional teacher training," The Inservice Education and Training of School Teachers, vol. 30, no. 10, pp. 9-11, 2013.

[3] Y. Li, "Principles for constructing curriculum system of foreign optional courses," Journal of Liaoning Technical University(Social Science Edition), vol. 13, no. 6, pp. 658-660, 2011.

[4] J. Tian, "On the cultural differences between China and Japan and the cultural infiltration in Japanese teaching," Journal of Weifang Engineering Vocational College, vol. 27, no. 1, pp. 102-103, 2014.

[5] J. Peng, " A discussion on the guiding role of the differences between Japanese and Japanese in the teaching of Japanese," China Education Innovation Herald, vol. 38, no. 35, pp. 77, 2009.

[6] J. F. Xi, "To explore the input of culture in college Japanese teaching method," Shanxi Youth, vol. 41, no. 14, pp. 172, 2016.

[7] L. Q. Chen, L. Gao, "The role and relationship of training objectives and curriculum system in personnel training," Journal of Chifeng University (Natural Science Edition), vol. 30, no. 2, pp. 270-272 2014. 